\author{
International Journal of Sustainable Development \& World \\ Policy \\ 2022 Vol. 11, No. 1, pp. 1-17. \\ $\operatorname{ISSN}(e): 2305-705 \mathrm{X}$ \\ $\operatorname{ISSN}(p): 2306-9929$ \\ DOI: 10.18488/26.v11i1.2898 \\ (C) 2022 Conscientia Beam. All Rights Reserved.

\title{
THE IMPACT OF TECHNOLOGICAL INNOVATION, RESEARCH AND DEVELOPMENT, AND ENERGY INTENSITY ON CARBON EMISSIONS: AN EXPERIENCE FROM BRICS AND OECD COUNTRIES
}

\section{Xu Xiaoyang ${ }^{1}$ \\ D Maurice Balibae \\ Kanaado $^{2+}$ \\ Motswedi Epadile ${ }^{3}$}

\section{Article History}

Received: 17 November 2021 Revised: 20 December 2021 Accepted: 4 January 2022 Published: 14 January 2022

\section{Keywords}

Ecological innovation Carbon emission

Two-stage least square method

Panel generalized method of

moments

BRICS countries

OECD countries.

JEL Classification: Oo0, O30, Q55.

\author{
1,2,s Jiangsu University, School of Finance and Economics, China. \\ Email:xiaoyangxu@ujs.edu.cn \\ 'Email:Kanaadomaurice@gmail.com Tel: +8618651289203 \\ ${ }^{s}$ Email: 5102190207@stmail.ujs.edu.cn Tel: +8615724806155
}

ABSTRACT

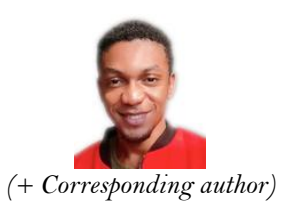

The impact of technological innovation, research and development, and energy intensity on carbon dioxide emissions is examined in this study. A panel data econometric analysis of relevant variables extracted from the OECD and World Development Indicators databases for 36 OECD and 5 BRICS countries from 2005 to 2018 reveals that the Kao panel cointegration test revealed all countries, BRICS countries, and OECD countries exhibited cointegrated relationships regarding the selected variables. At this point, the correlation matrix shows that none of the independent variables has a strong correlation coefficient with the dependent variable. We also used two regression methods to evaluate the long-run association between the study's variables; the two-stage least square (2SLS) and panel generalized method of moments (GMM) both provide similar results, indicating that they are robust. According to the findings, technological innovation and $R \& D$ have a positive association with $\mathrm{CO} 2$ emissions, but energy intensity has a negative relationship with $\mathrm{CO} 2$ emissions.

Contribution/Originality: This paper contributes to the existing literature by examining the impact of technological innovation, research and development and energy intensity on carbon emissions within the surroundings of both BRICS and OECD countries which has not been incorporated in previous studies.

\section{INTRODUCTION}

We live in a time of rapid technical advancements, with the majority of these advancements occurring in developed countries. Nonetheless, the fast economic expansion that we observe today began with the first industrial revolution. Technological innovation plays a crucial role in the economy we live in today as Western Europe and its offshoots - Australia, Canada, New Zealand, and the United States - as well as Japan, surged ahead with waves of technological progress at a time when per capita income disparities across countries were much narrower (Niu, 2021). These innovations have played a significant role in boosting productivity and improving people's livelihoods worldwide. For example, AI paired with robotics has revolutionized manufacturing and business processes. 3D printing enables low-volume production to be completed faster and at a lower cost and rapid, iterative development of new goods. These 11 technologies collectively represent a $\$ 350$-billion market, potentially increasing to approximately $\$ 3.2$ trillion by 2025 (Geneva, 2021). 
As a result of economic globalization, developing countries must innovate to maintain a quick economic growth rate and strengthen industrial structures and infrastructures to combat poverty (Asare \& Hongli, 2020). In the media and academia, the concept of BRICS has gotten a lot of attention. BRICS countries share several traits, including a vast population, a developing economy with rapid growth, and a determination to participate in the global market. The BRICS economy has been progressively prosperous over the last 60 years. According to Goldman Sachs' study, the BRICS might have a more significant role in the global economy than the OECD (the United States, Japan, Germany, France, Italy, and the United Kingdom) in less than 40 years, with BRICS economies accounting for more than half of the OECD economies by 2025. In particular, according to the most recent research of Liu, Ma, Ren, and Zhao (2020) by 2050, the BRICS countries' gross domestic product (GDP) is predicted to surpass that of the developed economies of the OECD. BRICS nations rely on high-energy-consuming industries like mining and manufacturing for economic growth and industrialization, contributing to considerable increases in $\mathrm{CO} 2$ emissions. As the environment deteriorates, we become more aware of the growing $\mathrm{CO}_{2}$ emissions that impact the global greenhouse effect and global economic development.

The overwhelming evidence suggests that global warming is primarily caused by an increase in $\mathrm{CO} 2$ levels in the atmosphere and that the increase in $\mathrm{CO} 2$ concentration is related to human activities (Asare \& Barfi, 2021 ; Willems \& Baumert, 2003). According to the organization's position, climate change induced by carbon dioxide emissions is harming the world's long-term development. It has been a source of heated dispute in international political, economic, and diplomatic circles (Liu et al., 2020). Anthropogenic $\mathrm{CO} 2$ emissions to the atmosphere totalled $2040 \pm 310$ GTCO 2 between 1750 and 2011 . Roughly $40 \%$ of these emissions (880 \pm 35 GTCO2) remained in the atmosphere; the rest were removed from the atmosphere and stored on land (in plants and soils) and in the ocean. Climate change jeopardizes people's lives by limiting access to water, food, medical care, and land. To reduce $\mathrm{CO} 2$ emissions, it is critical to reduce fossil fuels and increase the use of renewable energy. $\mathrm{CO} 2$ emissions are not only harmful to the biophysical ecosystem's health, but they also have a significant impact on human society. $\mathrm{CO} 2$ emissions, linked to climate change, have long been referred to as a "super wicked problem" that negatively influences human well-being. As a result, building a thriving energy resource economical and social integration is a significant problem for all countries worldwide (Liu et al., 2020; Vitenu-Sackey \& Bathuure, 2020).

Researchers have expressed various views on whether existing technologies are ready to cut $\mathrm{CO} 2$ emissions while presenting a variety of viewpoints. One of the most optimistic conclusions reached by the (IPCC) in its Third Assessment Report, published in 2001, is that: Over the next 100 years or more, known technical possibilities could provide a broad range of atmospheric stabilization levels, such as $550 \mathrm{ppm}, 450 \mathrm{ppm}$, or below. The term "known technical choices" refers to technologies that are currently in use or the pilot plant stage. It excludes any new technology that would necessitate a significant technological leap." Other recent publications, while not as authoritative as the IPCC, highlight the challenges.

For example, the IPCC's conclusion was disputed by Hoffert et al. (2002) as a "misperception of technological readiness." Instead, they conclude that more research into such technology is required - a need they claim is not commonly recognized. According to innovation theory, the fundamental cause for private enterprises' underinvestment in research and development activities is spillover. On the other hand, international spillovers are increasingly considered potentially beneficial feedback for environmental control technology R\&D. Renewable energy technologies that are competitive in OECD markets may have tremendous global benefits, allowing underdeveloped countries to reduce $\mathrm{CO} 2$ emissions at a reasonable cost (Baker, Clarke, \& Weyant, 2006; Cheng et al., 2020; Willems \& Baumert, 2003).

Studies on the microscopic mechanisms determining the consequences of technological innovation, $\mathrm{R} \& \mathrm{D}$, and energy intensity on $\mathrm{CO} 2$ emissions in all countries, BRICS countries, and OECD countries have yet to be undertaken. Previous research looked at how technological innovation affected carbon emissions, regional energy intensity, and pollutant emissions and how to formulate feasible co-responding measures using statistical models, 
econometric regression models, and general computational equilibrium (GCE) models. Hence, the research aims to look at the impact of all these variables in relation to carbon dioxide emissions within the settings of ALL COUNTRIES, BRICS, and OECD countries.

\section{LITERATURE REVIEW}

\subsection{The Relationship between Technological Innovation and $\mathrm{CO}_{2}$ Emission}

There is always the risk that rapid technological change will cause more harm than good at some point or accentuate inequalities. Carbon emission has drawn the attention of researchers in recent times. Some studies analyzed the critical relationship between energy and technological innovations (Bala \& Kumar, 2011; Wurlod \& Noailly, 2018).

Researchers such as Santra (2017) are looking into whether environmental-related technological innovation might promote performance energy consumption and Carbon dioxide emission effectiveness. His article concentrated on the BRICS countries to attain the stated goal. According to OECD figures, manufacturing energy efficiency, or output per energy employed, was used to quantify energy efficiency in the manufacturing sector. $\mathrm{CO} 2$ emission efficacy was determined using energy-related $\mathrm{CO}_{2}$ emission efficiency or production per unit of $\mathrm{CO} 2$ emission. Recent research, such as (Mulder \& De Groot, 2012; Voigt, De Cian, Schymura, \& Verdolini, 2014) show that their drop is primarily due to advances within industries rather than across sectors. Indicating that, rather than a composition influence, such as a shift to cleaner sectors of the economy, the decrease in aggregate energy intensity is due to more efficient energy use within businesses. There are two critical sources of improvement within the sector: input substitution - when companies replace energy with additional labour or capital, for example - and technological innovation - when companies save energy by employing more energy-efficient production procedures.

\subsection{Impact of Investment in REDD Technologies on Carbon Emission}

Several technology proxies have been found in the current literature, including R\&D knowledge innovation, patents, and high-tech exports. Numerous studies have examined how innovation may alter energy pricing, energy reliance, energy use, and energy output. However, just a few research have looked into the factors that influence energy intensities. Fisher-Vanden, Jefferson, Liu, and Tao (2004) looked into the elements that lead to a decline in China's energy intensity levels. The authors did so by analyzing data from 25 businesses from 1997 to 1999.

Many researchers examine the factors impacting $\mathrm{CO} 2$ emissions in the BRICS countries, and many of these researchers use statistical methods and regression models. For example, from 1996 to 2014, Wang and Zhang employed the least square approach to perform empirical research on $\mathrm{R} \& \mathrm{D}$ spending and $\mathrm{CO} 2$ emissions in the BRICS countries. Increasing R\&D expenditure, according to their findings, has a favourable impact on the decoupling of economic growth and environmental strain. Takanabe et al. (2010) tried to study the correlation between urbanization and $\mathrm{CO} 2$ emissions in BRICS countries from 1985 to 2014. Their findings show a long-term equilibrium cointegration relationship between urbanization and $\mathrm{CO} 2$ emissions. In this situation, businesses would be willing to invest in innovative, ecologically friendly technologies (Ding et al., 2021; Goulder \& Mathai, 2000; Goulder. \& Schneider, 1999). According to Carraro and Siniscalco (1994) the environmental management system has two roles in the economic process. Businesses can employ or purchase existing "cleaner" technology on the one hand or invest in R\&D to develop new "cleaner" technology (Requate \& Unold, 2003; Santra, 2017; Socolow, Hotinski, Greenblatt, \& Pacala, 2004). Their motivation for the latter is frequently boosted because present clean technology is not widely adopted due to its high-cost structure. Firms aim to invest in R\&D to develop new technological advancements that use less energy and emit fewer (Aghion, Hemous, \& Veugelers, 2009; Requate \& Unold, 2003). As a result, in the long run, businesses recognize that investing in R\&D is a requirement for getting environmental technology (Baker et al., 2006; Carraro \& Siniscalco, 1996; Jaffe, Newell, \& Stavins, 2005). 


\subsection{Green Innovation on Energy Intensity within BRICS and OECD Countries}

In recent studies by Wurlod and Noailly (2018) their paper focused on the impact of green innovation on energy intensity in a set of 14 industrial sectors in 17 OECD countries. For each industrial sector, they created a library of green patents. They used a translog cost function to measure the influence of green innovation on energy intensity, as well as other aspects such as input substitution and autonomous technical change. According to their findings, green innovation has contributed to a reduction in energy intensity in most sectors. In our dataset, the median energy intensity elasticity for green patenting is calculated to be -0.03. As a result, a $1 \%$ increase in green patenting activities in one industry is linked to a 0.3 per cent reduction in that sector's energy intensity.

Researchers such as Wang and Zhang (2020) are trying to assess whether more lavish R\&D spending helps BRICS countries decouple economic growth from carbon emissions. According to their findings, every $1 \%$ increase in research and development investment reduces carbon emissions by 0.8122 per cent for the BRICS, implying that increasing $\mathrm{R} \& \mathrm{D}$ investment has a favourable influence on decoupling economic expansion from environmental pressure. Individually, China has the most impact, while Russia and India have the least. This suggests that increased R\&D spending alone will not be sufficient to decouple economic growth and carbon emissions.

According to the Global Environment Outlook (Seager, Bechtel, Bock, \& Dankelman, 2016) and the OECD Forecast (Ball, 2014; Santra, 2017) the rising level of energy demand, as well as the high amount of energy intensity in the manufacturing process, are critical concerns for the BRICS countries. However, 'partly due to displacement effects and the delocalization of enterprises and sectors to rising countries,' the BRICS countries have taken no substantial moves to decouple energy inputs from their production systems (Pao \& Tsai, 2011; Santra, 2017). As a result, in growing economies such as the BRICS, financial development, carbon and energy productivity have become the most critical variables driving $\mathrm{CO} 2$ emissions (Santra, 2017; Vitenu-Sackey., 2020). As a result, both BRICS and OECD countries must urgently assess the effects of environmental policies such as environmental legislation, energy taxation/subsidies, technical innovation, and increased investment in R\&D for developing new environment-related technologies. However, no research has been done in the BRICS and OECD to look into the impact of technological innovation, research and development, and energy intensity on carbon emissions in the production sectors. The goal of this article is to look at the impact of technological innovation, research and development and energy intensityon carbon dioxide emission across all countries, including BRICS and OECD countries.

\section{METHODS AND DATA}

\subsection{Method}

We adopted some econometric approaches to achieve our objective, such as (i) estimation of cross-sectional dependence across the panel was executed to ascertain the existence of cross-sectional dependence; (ii) unit root test performed to cement the stationarity status of the data series after cross-sectional dependence realized; (iii) subsequently, Kao panel cointegration test performed to fish out the long-run equilibrium or relationship that exist among the study's variables; (iv) correlation matrix is computed at this stage as an approach to find out the correlation between the endogenous and the exogenous variables; also to check for the problem of multicollinearity (v) at this step, we utilized two regression techniques to analyze the long-run relationship between the variables in the study thus two-stage least square (2SLS) and panel generalized method of moments (GMM). By using these two robust methods, we intend to resolve the issues of endogeneity, heterogeneity, and simultaneity bias that may arise in the model in estimating the marginal effects or parameter coefficients of the variables in the study.

However, we construct the model below for our econometric analyses:

$$
\begin{aligned}
\ln C O 2_{\mathrm{i}, \mathrm{t}}=\beta_{0}+ & \beta_{1} E I N T_{\mathrm{i}, \mathrm{t}}+\beta_{2} \ln P N T_{\mathrm{i}, \mathrm{t}}+\beta_{3} \ln R_{-} D_{\mathrm{i}, \mathrm{t}}+\beta_{4} \ln F D I_{\mathrm{i}, \mathrm{t}}+\beta_{5} \ln R E_{\mathrm{i}, \mathrm{t}}+\beta_{6} \ln U R P_{\mathrm{i}, \mathrm{t}}+\beta_{7} \ln G D P_{-} C A P_{\mathrm{i}, \mathrm{t}} \\
& +\beta_{8} \ln G D P_{-} C A P 2_{\mathrm{i}, \mathrm{t}}+\varepsilon_{\mathrm{i}_{i, \mathrm{t}}}
\end{aligned}
$$


In Equation $1 \operatorname{lnCO} 2$ represents the dependent variable which denotes carbon emissions per metric tonnes. EINT, InPNT, and lnR_D are the independent variables that indicate energy intensity, patent applications registration, and research and development. lnFDI, lnRE, lnURP, lnGDP_CAP2, and lnGDP_CAP are the control variables: foreign direct investment, renewable energy consumption, urbanization, and gross domestic product per capita and its quadratic term, correspondingly. The proxies $\beta_{1}$ to $\beta_{8}$ stands for the parameter coefficients to be estimated, and $\beta_{0}$ represents the slope coefficient to be estimated, and $\varepsilon$ represents the error term or stochastic disturbance in the proposed model.

3.2. Data

We sourced our data from OECD and World Development Indicators database from 2005 to 2018 for 36 OECD and 5 BRICS countries. The variables used in the study have been outlined in Table 9, and the countries used as samples are summarised in Table 10.

\section{FINDINGS AND DISCUSSION}

\subsection{Description Statistics}

Table 1 reports some descriptive statistics on $\mathrm{CO}_{2}$ emissions per capita for all BRICS and OECD countries. Within ALL COUNTRIES, the results reveal that only EINT and lnURP records negative average values as per capita $\mathrm{CO}_{2}$ emission during the period covered (-12.497 and -0.077 metric tons per capita, respectively). lnGDP_CAP and lnFDI display the highest average per capita $\mathrm{CO} 2$ emissions during the covered period (10.335 and 8.599 metric tons per capita, respectively). Also, 1nFDI has the highest standard deviation (Std. Dev) per capita $\mathrm{CO}_{2}$ emission value among all variables, with $\operatorname{lnGDP} \_\mathrm{CAP} 2$ recording the lowest standard deviation (Std. Dev) value of (3.066 and 0.091 , respectively). $\operatorname{lnCO} 2, \ln \mathrm{PNT}, \operatorname{lnR} \_\mathrm{D}, \operatorname{lnRE}$, and $\operatorname{lnGDP}$ CAP2 have a corresponding average per capita of $2.008,5.135,1.222,2.630$, and 3.213 , respectively.

EINT is the only variable with a negative average value as per capita $\mathrm{CO} 2$ emission during the period covered in the BRICS economy. In ranging from the highest value of the average per capita $\mathrm{CO}_{2}$ emission to the lowest value within the period covered, our findings show that lnFDI, lnGDP_CAP, lnR_D, lnPNT, lnRE, lnGDP_CAP2, $\operatorname{lnCO} 2$, and $\operatorname{lnURP}$ has corresponding values of 9.660, 9.306, 6.274, 5.083, 4.452, 3.049, 1.774 and 0.335 respectively. Also, it is realized that 1nR_D has the highest standard deviation (Std. Dev) value of 5.306, followed by $\operatorname{lnRE}$, lnFDI, lnPNT, lnURP, EINT, lnGDP_CAP, $\operatorname{lnCO} 2$, and finally $\operatorname{lnGDP} C \mathrm{CAP} 2$ as the least.

While in OECD countries, only EINT and lnURP have an opposing average per capita $\mathrm{CO}_{2}$ emission of 12.698 and -0.138 , respectively. In ranging from the highest average variable to the lowest average per capita $\mathrm{CO}_{2}$ emission, we have lnGDP_CAP, lnFDI, lnPNT, lnGDP_CAP $2, \ln R E, \ln \mathrm{CO}_{2}$, and lnR_D with their corresponding values of $10.486,8.443,5.143,3.238,2.362,2.042$, and 0.478 , respectively. The variable with the highest standard deviation (Std. Dev) value is lnFDI with a corresponding value of 3.118, and lnGDP_CAP2 has the lowest standard deviation value of 0.060 .

\subsection{Unit Root Tests}

Understanding the stationarity level of the data series or variables requires a unit root test. Conversely, we performed unit root tests to reveal the stationarity status of the variables. The rule of thumb of the unit root test suggests that at $\mathrm{I}(\mathrm{O})$ and $\mathrm{I}(1)$, the null hypothesis of the unit root should be rejected at a $5 \%$ significance level or less. Specifically, we utilized the methods of Im, Pesaran, and Shin (2003); Levin, Lin, and Chu (2002); Maddala and $\mathrm{Wu}$ (1999). The results suggest that the null hypothesis of unit root is rejected for both level and first difference. All the tests performed the samples; thus, ALL countries, BRICS countries, and OECD countries depicted no evidence of unit root (see Tables 2, 3, 4). 
Table 1. Descriptive statistics of study's variables.

\begin{tabular}{|c|c|c|c|c|c|}
\hline All Countries & Mean & Std. Dev. & Jarque-Bera & Probability & Observations \\
\hline $\ln \mathrm{CO} 2$ & 2.008 & 0.444 & 3.991 & 0.136 & 546 \\
\hline EINT & -12.497 & 0.772 & 49.880 & 0.000 & 546 \\
\hline $\ln \mathrm{PNT}$ & 5.135 & 2.187 & 11.651 & 0.003 & 546 \\
\hline $\operatorname{lnR} \mathrm{D} D$ & 1.222 & 2.767 & 2439.266 & 0.000 & 546 \\
\hline $\ln \mathrm{FDI}$ & 8.599 & 3.066 & 433.432 & 0.000 & 546 \\
\hline $\ln \mathrm{RE}$ & 2.630 & 1.836 & 8105.158 & 0.000 & 546 \\
\hline $\ln U R P$ & -0.077 & 0.834 & 1620.543 & 0.000 & 546 \\
\hline $\operatorname{lnGDP} \_C A P 2$ & 3.213 & 0.091 & 318.223 & 0.000 & 546 \\
\hline lnGDP_CAP & 10.335 & 0.572 & 243.348 & 0.000 & 546 \\
\hline \multicolumn{6}{|l|}{ Brics Countries } \\
\hline $\ln \mathrm{CO} 2$ & 1.774 & 0.443 & 3.494 & 0.174 & 70 \\
\hline EINT & -11.129 & 0.573 & 2.838 & 0.242 & 70 \\
\hline $\ln \mathrm{PNT}$ & 5.083 & 1.467 & 7.281 & 0.026 & 70 \\
\hline lnR_D & 6.274 & 5.306 & 9.495 & 0.009 & 70 \\
\hline $\operatorname{lnFDI}$ & 9.660 & 2.456 & 106.738 & 0.000 & 70 \\
\hline $\ln R E$ & 4.452 & 4.096 & 19.104 & 0.000 & 70 \\
\hline $\operatorname{lnURP}$ & 0.335 & 1.040 & 95.648 & 0.000 & 70 \\
\hline lnGDP_CAP2 & 3.049 & 0.093 & 4.510 & 0.105 & 70 \\
\hline lnGDP_CAP & 9.306 & 0.562 & 3.863 & 0.145 & 70 \\
\hline \multicolumn{6}{|l|}{ OECD Countries } \\
\hline $\ln \mathrm{CO} 2$ & 2.042 & 0.434 & 8.611 & 0.013 & 476 \\
\hline EINT & -12.698 & 0.565 & 9.965 & 0.007 & 476 \\
\hline $\ln \mathrm{PNT}$ & 5.143 & 2.275 & 12.654 & 0.002 & 476 \\
\hline $\ln \mathrm{R}_{-} \mathrm{D}$ & 0.478 & 0.616 & 42.421 & 0.000 & 476 \\
\hline $\ln \mathrm{FDI}$ & 8.443 & 3.118 & 345.406 & 0.000 & 476 \\
\hline $\ln \mathrm{RE}$ & 2.362 & 0.933 & 5.525 & 0.063 & 476 \\
\hline $\operatorname{lnURP}$ & -0.138 & 0.782 & 6.923 & 0.031 & 476 \\
\hline $\operatorname{lnGDP}{ }_{1} \mathrm{CAP}_{2}$ & 3.238 & 0.060 & 8.054 & 0.018 & 476 \\
\hline lnGDP_CAP & 10.486 & 0.387 & 2237.091 & 0.000 & 476 \\
\hline
\end{tabular}

Subsequently, we performed a cross-sectional dependence test to ascertain the correspondence of the error terms with individual cross-sections. The results of the cross-sectional dependence test can be found in Table 2 for all countries sample, Table 3 for BRICS countries sample, and Table 4 for OECD countries sample. We observed in the all-countries sample, lnR_D and lnURP could substantiate the cross-sectional dependence assumption. Also, lnFDI and lnR_D could not verify the cross-sectional dependence assumption in the BRICS countries sample, and lnURP also could not verify the cross-sectional dependence assumption in the OECD countries. The revelation suggests that in selecting the regression estimator, we have to opt for the one that could resolve the cross-sectional independence witnessed from the respective samples' variables to avoid inconsistency and invalid estimations.

\subsection{Cointegration Test}

Table 5 presents the cointegration test performed with the Kao (1999) method. Based on the results, we strongly reject the null hypothesis of cointegration in a sense that, at $1 \%$ and $5 \%$ significance levels, all the test suggests a cointegration relationship among the variables. Hence, there is a long-run relationship between the dependent and the independent variables. Specifically, all samples; thus, all countries, BRICS countries, and OECD countries portrayed cointegrated relationships regarding the selected variables. 


\begin{tabular}{|c|c|c|c|c|c|c|c|c|c|c|}
\hline \multicolumn{2}{|c|}{ All countries } & EINT & $\ln \mathrm{CO} 2$ & $\operatorname{lnFDI}$ & lnGDP_CAP & lnGDP_CAP2 & $\operatorname{lnPNT}$ & lnR_D & $\ln R E$ & $\operatorname{lnURP}$ \\
\hline \multirow[t]{4}{*}{ Level } & LLC & $-3.159 * * *$ & $-2.211 * *$ & -38.767 **** & $-9.225^{* * * *}$ & $-9.802^{* * * *}$ & $-5.224 * * *$ & $-6.089^{* * * *}$ & 0.745 & $-5.702 * * *$ \\
\hline & IPS & 3.775 & 2.776 & $-15.399^{* * * *}$ & 0.899 & 0.561 & $-3.795 * * *$ & $-3.757 * * *$ & $-4.395 * * *$ & $-6.456^{* * * *}$ \\
\hline & ADF-Fisher & 54.938 & 51.229 & 253.596**** & 98.417 & $102.163 * *$ & $146.086^{* * * *}$ & $147.680^{* * * *}$ & $150.517 * * *$ & $164.488^{* * * *}$ \\
\hline & PP-Fisher & 120.213 & 54.897 & 272.284 **** & $134.799^{* * * *}$ & 138.257 **** & $190.778^{*} * *$ & $140.049^{* * * *}$ & $249.853^{* * * *}$ & $97.983^{* *}$ \\
\hline \multicolumn{11}{|c|}{ First Difference } \\
\hline & LLC & $-16.502^{*} * *$ & $-20.047 * * *$ & $-34.527 * * *$ & -15.617 **** & $-15.594 * * * *$ & $-22.132 * * *$ & $-26.920 * * * *$ & $-133.886 * * *$ & $-10.223 * * *$ \\
\hline & IPS & $-12.449^{* * * *}$ & $-15.061^{* * * *}$ & $-23.661 * * *$ & $-11.513^{* * * *}$ & $-11.566^{* * * *}$ & $-17.629^{* * * *}$ & $-13.967 * * * *$ & $-41.663^{* * * *}$ & $-10.515^{* * * *}$ \\
\hline & ADF-Fisher & 286.736 **** & 337.696 *** & 450.275 **** & 267.986 **** & $268.928 * * * *$ & $387.243^{*} * *$ & $262.311 * * * *$ & $352.550^{* * * *}$ & $246.985 * * *$ \\
\hline & PP-Fisher & 319.645 **** & $424.900^{* * * *}$ & 672.937 **** & $369.563^{* * * *}$ & $374.295^{*} * *$ & $499.170^{* * * *}$ & $293.700^{* * * *}$ & $342.788^{* * * *}$ & 273.239 **** \\
\hline \multicolumn{11}{|c|}{ Cross-sectional dependence } \\
\hline & Breusch-Pagan LM & $8238.838^{* * * *}$ & $5782.496^{* * * *}$ & $893.715^{* * * *}$ & $8569.581 * * * *$ & $8570.310^{* * * *}$ & $2175.264 * * * *$ & & $3946.516^{* * * *}$ & \\
\hline & Pesaran scaled LM & $194.766^{* * * *}$ & $130.959^{* * * *}$ & $3.967 * * *$ & $203.357 * * *$ & $203.376^{* * * *}$ & $37.257 * * *$ & & $83.267 * * *$ & \\
\hline & Bias-corrected scaled LM & $193.266^{* * * *}$ & $129.459^{* * * *}$ & 2.467 *** & $201.857 * * *$ & $201.876^{* * * *}$ & $35.757 * * *$ & & $81.767 * * *$ & \\
\hline & Pesaran CD & $87.254 * * * *$ & $29.340 * * *$ & $4.072^{* * * *}$ & $89.820 * * * *$ & $89.829 * * * *$ & $9.031 * * *$ & & $11.397 * * *$ & \\
\hline
\end{tabular}

Note: **** denote p-value $\leq 0.001$, *** denote p-value $\leq 0.05$, * denote p-value $<0.10$.

Table 3. Unit root tests for BRICS Countries.

\begin{tabular}{|c|c|c|c|c|c|c|c|c|c|c|}
\hline \multicolumn{2}{|c|}{ BRICS Countries } & \multirow{2}{*}{$\begin{array}{c}\text { EINT } \\
-4.537^{* * * *}\end{array}$} & \multirow{2}{*}{$\begin{array}{c}\operatorname{lnCO2} \\
-3.427^{* * * *} *\end{array}$} & \multirow{2}{*}{$\begin{array}{c}\operatorname{lnFDI} \\
-3.546^{* * * *}\end{array}$} & \multirow{2}{*}{$\frac{\mid \text { lnGDP_CAP }}{-10.481^{* * * *}}$} & \multirow{2}{*}{$\begin{array}{c}\text { lnGDP_CAP2 } \\
-10.953^{* * * *}\end{array}$} & \multirow{2}{*}{$\begin{array}{c}\operatorname{lnPNT} \\
-0.605\end{array}$} & \multirow{2}{*}{$\begin{array}{c}\text { lnR_D } \\
-4.239^{* * * *}\end{array}$} & \multirow{2}{*}{$\begin{array}{l}\operatorname{lnRE} \\
0.668\end{array}$} & \multirow{2}{*}{$\frac{\operatorname{lnURP}}{-3.845^{* * * *}}$} \\
\hline Level & $\overline{\text { LLC }}$ & & & & & & & & & \\
\hline & IPS & $-2.246^{* *}$ & -1.441 & $-4.020 * * *$ & $-7.149^{* * * *}$ & $-7.468^{* * * *}$ & 0.466 & $-2.383 * *$ & 0.429 & $-1.964^{* *}$ \\
\hline & ADF-Fisher & $22.048^{* * *}$ & $18.134^{* *}$ & $33.258 * * *$ & $54.562 * * *$ & $56.394^{* * * *}$ & 10.686 & $17.035^{* * *}$ & 13.342 & $24.920^{* *}$ \\
\hline & PP-Fisher & $56.293^{* * *}$ & 16.945 & $45.270^{* * * *}$ & $74.296^{* * * *}$ & $74.710^{* * * *}$ & 11.651 & 22.143 *** & 11.349 & 14.891 \\
\hline \multicolumn{11}{|c|}{ First Difference } \\
\hline & LLC & $-3.621 * * *$ & $-6.107 * * *$ & $-7.345 * * *$ & $-3.267 * * *$ & $-3.280 * * *$ & $-9.856^{* * * *}$ & $-1.795^{* *}$ & -5.661 **** & $-2.254 * *$ \\
\hline & IPS & $-2.380^{* *}$ & $-4.628 * * *$ & $-6.431 * * *$ & -1.507 & -1.528 & $-7.914^{* * * *}$ & $-1.730^{* *}$ & $-4.571 * * *$ & $-1.736^{* *}$ \\
\hline & ADF-Fisher & $24.889^{* *}$ & $37.582^{* * * *}$ & $50.871^{* * * *}$ & 17.479 & 17.506 & 61.467 *** & $12.354 * *$ & $38.663^{* * * *}$ & $19.610^{* * *}$ \\
\hline & PP-Fisher & $22.363^{* *}$ & $45.430^{* * * *}$ & $70.943 * * *$ & $18.576^{* *}$ & $18.679^{* *}$ & $90.105 * * *$ & $11.889^{* * *}$ & $57.292 * * *$ & 15.769 \\
\hline \multicolumn{11}{|c|}{ Cross-sectional dependence } \\
\hline & Breusch-Pagan LM & $101.321^{* * * *}$ & $43.154^{* * * *}$ & & $123.094 * * * *$ & $123.362^{* * * *}$ & 55.230 **** & & $38.478^{* * * *}$ & $47.078^{* * * *}$ \\
\hline & Pesaran scaled LM & $20.420^{* * *}$ & $7.414^{* * * *}$ & & $25.288^{* * * *}$ & $25.349^{* * *}$ & $10.114^{* * * *}$ & & $6.368^{* * *}$ & $8.291^{* * * *}$ \\
\hline & Bias-corrected scaled LM & $20.228^{* * * *}$ & $7.221^{* * * *}$ & & $25.096^{* * * *}$ & $25.156^{* * * *}$ & $9.921^{* * * *}$ & & $6.176^{* * * *}$ & $8.099^{* * * *}$ \\
\hline & Pesaran CD & $9.952^{* * * *}$ & $4.042^{* * * *}$ & & $11.087^{* * * *}$ & $11.099 * * *$ & -1.025 & & 1.504 & $2.724^{* * *}$ \\
\hline
\end{tabular}




\begin{tabular}{|c|c|c|c|c|c|c|c|c|c|c|}
\hline \multicolumn{2}{|c|}{ OECD Countries } & EINT & $\ln \mathrm{CO} 2$ & $\operatorname{lnFDI}$ & lnGDP_CAP & lnGDP_CAP2 & $\operatorname{lnPNT}$ & $\operatorname{lnR} \_D$ & $\operatorname{lnRE}$ & $\operatorname{lnURP}$ \\
\hline \multirow[t]{4}{*}{ Level } & LLC & -1.343 & -0.602 & -39.741 **** & $-3.542 * * *$ & $-3.858 * * *$ & $-6.537 * * *$ & $-5.224 * * *$ & 0.575 & $-4.681 * * *$ \\
\hline & IPS & 4.949 & 3.492 & -14.967 **** & 3.615 & 3.373 & $-4.243^{*} * *$ & $-3.214^{* * *}$ & $-4.863 * * * *$ & $-6.165^{* * * *}$ \\
\hline & ADF-Fisher & 32.889 & 33.095 & $220.338^{* * * *}$ & 43.856 & 45.768 & $135.399^{* * * *}$ & 130.645 **** & $137.175^{* * * *}$ & $159.568^{* * * *}$ \\
\hline & PP-Fisher & 63.919 & 37.952 & $227.014^{* * * *}$ & 60.503 & 63.546 & $179.126^{* * * *}$ & $117.906^{* * * *}$ & $238.504 * * * *$ & 83.092 \\
\hline \multicolumn{11}{|c|}{ First Difference } \\
\hline & LLC & -16.473 *** & $-19.170^{* * * *}$ & $-34.001 * * *$ & $-15.895 * * *$ & $-15.919 * * *$ & $-20.240^{* * * *}$ & $-26.933^{*} * *$ & -135.340 **** & $-11.004 * * *$ \\
\hline & IPS & $-12.413^{* * * *}$ & $-14.350^{* * * *}$ & $-22.885^{* * * *}$ & $-11.729^{* * * *}$ & $-11.778^{* * * *}$ & $-15.835^{* * *}$ & $-14.051^{* * * *}$ & $-42.878^{*} * *$ & $-10.600^{* * * *}$ \\
\hline & ADF-Fisher & 261.847 *** & $300.114^{*} * * *$ & 399.403**** & $250.508^{*} * *$ & $251.422^{* * * *}$ & 325.776**** & 249.957 **** & 313.887 **** & $227.376^{* * * *}$ \\
\hline & PP-Fisher & $297.283^{* * *}$ & $379.470^{* * * *}$ & $601.944^{* * * *}$ & 350.987 **** & $355.616^{* * * *}$ & 409.064**** & $281.811^{* * * *}$ & $285.496^{* * * *}$ & $257.470^{* * * *}$ \\
\hline \multicolumn{11}{|c|}{ Cross-sectional dependence } \\
\hline & Breusch-Pagan LM & $6444.825^{* * *}$ & $4716.586^{* * * *}$ & $684.112^{* * * *}$ & $6652.599^{* * * *}$ & $6651.627^{*} * * *$ & $1590.776^{* * * *}$ & $2016.969 * * *$ & $3186.991^{* * * *}$ & \\
\hline & Pesaran scaled LM & $175.656^{* * * *}$ & $124.061^{* * * *}$ & $3.675^{* * * *}$ & $181.859^{* * * *}$ & $181.830^{* * * *}$ & $30.743^{*} * *$ & $43.467^{* * * *}$ & 78.397 **** & \\
\hline & Bias-corrected scaled LM & $174.348^{* * * *}$ & $122.754 * * *$ & $2.368^{* * *}$ & $180.551 * * * *$ & $180.522^{* * * *}$ & $29.435 * * *$ & $42.159^{* * *}$ & $77.089^{* * * *}$ & \\
\hline & Pesaran CD & $77.415^{* * * *}$ & $41.576^{* * * *}$ & $3.876^{* * *}$ & 79.039 **** & $79.036^{* * * *}$ & $10.872 * * *$ & $11.751 * * *$ & $16.311 * * *$ & \\
\hline
\end{tabular}


Table 5. Cointegration test.

\begin{tabular}{|c|c|c|c|}
\hline \multicolumn{4}{|c|}{ Kao Residual Cointegration Test } \\
\hline \multicolumn{4}{|l|}{ All Countries } \\
\hline & t-Statistic & Prob. & Sig. \\
\hline ADF & -5.409 & 0.000 & **** \\
\hline \multicolumn{4}{|c|}{ BRICS Countries } \\
\hline & t-Statistic & Prob. & \\
\hline $\mathrm{ADF}$ & -2.926 & 0.002 & $* *$ \\
\hline \multicolumn{4}{|c|}{ OECD Countries } \\
\hline & t-Statistic & Prob. & \\
\hline $\mathrm{ADF}$ & -4.873 & 0.000 & **** \\
\hline
\end{tabular}

\subsection{Correlation Matrix}

Table 6 exhibits the outcome of the correlation matrix, and it is evident none of the independent had a high correlation coefficient with the dependent variable. Therefore, we reject the assumption of multicollinearity in our proposed model. The rule of thumb assumes that when an independent variable reveals a correlation coefficient of / +0.70 or more with the dependent variable, then the problem of collinearity would ensue in the model. Also, when two or more exhibit the same coefficients, then the problem of multicollinearity would occur, which could lead to heteroskedasticity and would, in turn, lead to spurious regression when it is performed.

In contrast, lnGDPCAPS, lnGDPCAP, lnR_D, and lnFDI depict a positive correlation with $\operatorname{lnCO} 2$, but $\operatorname{lnFDI}$ shows an insignificant coefficient or correlation. On the other hand, EINT, lnRE, and lnURP exhibited a negative and significant correlation with $\operatorname{lnCO} 2$.

\subsection{Long-Run Parameter Estimations}

Table 7 below shows that a considerable volume of energy usage enhances the environmental performance Index of all BRICS and OECD countries. Hence, the findings from the long-run parameter estimation of all the variables. From the outcome, EINT has a positively significant long-run relation with all countries simultaneously; it also has a significant positive relationship when separated; thus, BRICS and OECD countries remain positively significant at EINT. Energy consumption has a considerable beneficial impact on economic growth, which is essential for continuing economic expansion. Nonetheless, the rapid rate of $\mathrm{CO} 2$ emissions needs the adoption of alternative energy sources and advancements in environmental protection. According to Nawaz et al. (2021) a large portion of carbon dioxide emissions, 94.5437 per cent, is justified by current impacts related to carbon emissions, which is consistent with the findings below. Their findings show that the usage of renewable energy resources reduces greenhouse gas emissions in both BRICS and OECD economies, as predicted by Nawaz et al. (2021); Németh-Durkó (2020); Sharma, Sinha, and Kautish (2021).

The variables $1 \mathrm{nPNT}$ and $1 \mathrm{nFDI}$ both are positively significant at all countries, and when segregated, BRICS countries are negatively significant at $1 \mathrm{nPNT}$ and negatively insignificant at $1 \mathrm{nFDI}$. While at OECD countries, 1nPNT and 1nFDI are positively insignificant. This proves the finding of Santra (2017) that Technological innovation (1nPNT) has a positive relation with $\mathrm{CO}_{2}$ emission and plays a significant role in influencing $\mathrm{CO}_{2}$ emission in all countries and BRICS nations. According Liu et al. (2020) financial investment (1nFDI) has a significant favourable influence on Technological innovation (1nPNT); hence the use of renewable and nonrenewable energy combined will reduce $\mathrm{CO}_{2}$ emission. Financial Investment (1nFDI) has a significant positive relationship with $\mathrm{CO}_{2}$ emission in the long-term amongst all countries and OECD countries. It is discovered to have a negative impact on $\mathrm{CO}_{2}$ emission in the long-term amongst BRICS countries. Although these results are similar to most empirical evidence on EKC (Sinha \& Shahbaz, 2018; Soytas, Sari, \& Ewing, 2007) there might have different reasons. On the other hand, $1 \mathrm{nPNT}$ and $1 \mathrm{nFDI}$ are closely related. A change in one can have a negative or positive impact on the other. 
International Journal of Sustainable Development \& World Policy, 2022, 11(1): 1-17

\begin{tabular}{|c|c|c|c|c|c|c|c|c|c|}
\hline Correlation & & & & & & & & & \\
\hline Probability & $\operatorname{lnCO2}$ & EINT & $\operatorname{lnPNT}$ & lnR_D & lnFDI & $\ln R E$ & $\operatorname{lnURP}$ & $\operatorname{lnGDPCAP2}$ & $\operatorname{lnGDPCAP}$ \\
\hline $\ln \mathrm{CO} 2$ & 1 & & & & & & & & \\
\hline EINT & $-0.242^{* * * *}$ & 1 & & & & & & & \\
\hline $\operatorname{lnPNT}$ & $0.196^{* * * *}$ & $-0.259^{* * * *}$ & 1 & & & & & & \\
\hline lnR_D & $0.104 * *$ & $0.449^{* * * *}$ & $0.155^{* * *}$ & 1 & & & & & \\
\hline $\operatorname{lnFDI}$ & 0.0004 & 0.032 & $0.274 * * *$ & $0.099 * *$ & 1 & & & & \\
\hline $\ln \mathrm{RE}$ & $-0.293^{*} * *$ & $0.332^{* * * *}$ & 0.017 & $0.460^{* * * *}$ & $0.092 * *$ & 1 & & & \\
\hline $\ln U R P$ & $-0.102^{* *}$ & $0.122 * *$ & -0.034 & 0.061 & 0.063 & $0.245^{* * *}$ & 1 & & \\
\hline $\ln \mathrm{GDPCAP}_{2}$ & $0.510 * * *$ & $-0.878^{* * * *}$ & $0.217 * * *$ & $-0.305^{*} * *$ & $-0.103 * *$ & $-0.322^{*} * *$ & $-0.191 * * *$ & 1 & \\
\hline lnGDPCAP & $0.510 * * *$ & $-0.880^{*} * * *$ & $0.222 * * *$ & $-0.305^{*} * *$ & $-0.103 * *$ & $-0.319 * * *$ & $-0.183 * * *$ & $0.999 * * *$ & 1 \\
\hline
\end{tabular}


International Journal of Sustainable Development \& World Policy, 2022, 11(1): 1-17

Table 7. Long-run parameter estimations.

\begin{tabular}{|c|c|c|c|c|c|c|}
\hline $\mathrm{DV}=\ln \mathrm{CO} 2$ & 2SLS & & & $\begin{array}{c}\text { GMM } \\
\text { (PCSE) }\end{array}$ & & \\
\hline & $\begin{array}{c}\text { ALL } \\
\text { Countries }\end{array}$ & BRICS & OECD & $\begin{array}{c}\text { ALL } \\
\text { Countries }\end{array}$ & BRICS & OECD \\
\hline \multirow[t]{2}{*}{ EINT } & 0.506 & 0.165 & 0.579 & 0.506 & 0.165 & 0.579 \\
\hline & $(12.644)^{* * * *}$ & $(3.090)^{* * *}$ & $(14.072)^{* * * *}$ & $(22.992)$ **** & $(3.090)^{* * *}$ & $(14.072)^{* * * *}$ \\
\hline \multirow[t]{2}{*}{$\operatorname{lnPNT}$} & 0.021 & -0.010 & 0.003 & 0.021 & -0.010 & 0.003 \\
\hline & $(3.071)^{* *}$ & $(-1.885)^{*}$ & $(0.351)$ & $(6.015)^{* * * *}$ & $(-1.885)^{*}$ & $(0.351)$ \\
\hline \multirow[t]{2}{*}{ lnR_D } & 0.033 & 0.038 & -0.025 & 0.033 & 0.038 & -0.025 \\
\hline & $(5.361)^{* * * *}$ & $(8.186)^{* * * *}$ & $(-0.740)$ & $(13.327)^{* * *}$ & $(8.186)^{* * * *}$ & $(-0.740)$ \\
\hline \multirow[t]{2}{*}{$\operatorname{lnFDI}$} & 0.011 & -0.003 & 0.006 & 0.011 & -0.003 & 0.006 \\
\hline & $(2.459) * *$ & $(-1.194)$ & $(1.248)$ & $(2.786) * *$ & $(-1.194)$ & $(1.248)$ \\
\hline \multirow[t]{2}{*}{ lnGDPCAP } & 1.141 & 0.931 & 1.451 & 1.141 & 0.931 & 1.451 \\
\hline & $(17.447)^{* * * *}$ & $(11.564)^{* * * *}$ & $(14.556)^{* * * *}$ & $(34.252) * * *$ & $(11.564)^{* * * *}$ & $(14.556)^{* * * *}$ \\
\hline \multirow{2}{*}{$\ln \mathrm{GDPCAP} 2$} & -1.090 & -1.677 & -1.662 & -1.090 & -1.677 & -1.662 \\
\hline & $(-6.278)^{* * * *}$ & $(-22.024)$ **** & $(-6.125)^{* * * *}$ & $(-6.356) * * *$ & $(-22.024))^{* * *} *$ & $(-6.125))^{* * * *}$ \\
\hline \multirow[t]{2}{*}{$\operatorname{lnRE}$} & -0.075 & -0.026 & -0.204 & -0.075 & -0.026 & -0.204 \\
\hline & $(-9.028)^{* * * *}$ & $(-8.256)^{* * * *}$ & $(-13.207)^{* * * *}$ & $(-19.745)^{* * *}$ & $(-22.024)^{* * *}$ & $(-13.207)^{* * *}$ \\
\hline \multirow[t]{2}{*}{$\ln U R P$} & 0.043 & 0.033 & 0.005 & 0.043 & 0.033 & 0.005 \\
\hline & $(2.635)^{* *}$ & $(5.288)^{* * * *}$ & $(0.279)$ & $(4.9936) * * *$ & $(5.288)^{* * * *}$ & $(0.279)$ \\
\hline R-squared & 0.546 & 0.982 & 0.555 & 0.546 & 0.982 & 0.555 \\
\hline Adjusted R-squared & 0.540 & 0.980 & 0.548 & 0.540 & 0.980 & 0.548 \\
\hline J-statistics & & & & 0.863 & 2.529 & 39.768 \\
\hline Prob(J-statistic) & 0.353 & 0.112 & 0.867 & 0.353 & 0.112 & 0.867 \\
\hline Breusch-Pagan LM & $4657.785^{* * * *}$ & $19.908^{* *}$ & $3444.957 * * *$ & & & \\
\hline Pesaran scaled LM & $101.743 * * *$ & $2.216^{* * *}$ & $86.098 * * *$ & & & \\
\hline Pesaran CD & $41.699^{* * * *}$ & 1.101 & $45.274 * * *$ & & & \\
\hline
\end{tabular}

Note: **** denote p-value $\leq 0.001$ ( $1 \%$ significance level), ** denote p-value $\leq 0.05$ ( $5 \%$ significance level). 
1nR_D is positively significant at $1 \%$ in ALL COUNTRIES, and when segregated, it remains positively significant at $1 \%$ in BRICS countries and negatively insignificant at OECD countries. Hence, 1nR_D has a negative effect on $\mathrm{CO}_{2}$ emission in OECD nations but indicates a positive impact on both ALL and BRICS countries.

The associated growth amongst GDP growth and $\mathrm{CO}_{2}$ emissions for all countries, BRICS, and OECD countries have been examined, and the long-term findings portray that 1nGDPCAP is positively significant at all countries and remains positively significant when segregated at both BRICS and OECD countries. 1nGDPCAP results are inversely related to $1 \mathrm{nGDPCAP} 2$. Thus, 1 GGDPCAP 2 has a negatively significant value in all countries and remains negatively significant at both BRICS and OECD countries. Growth in 1nGDPCAP increases CO2 emissions, proving the EKC hypothesis in the OECD and BRICS regions.

The Table also shows that $1 \mathrm{nRE}$ is negatively significant in all countries and that $1 \mathrm{nRE}$ is negatively significant in both BRICS and OECD nations when separated. If all other parameters remain unchanged, a $1 \%$ increase in 1nRE consumption increases $\mathrm{CO} 2$ emissions in All BRICS and OECD countries by 0.075, 0.026, and 0.204, respectively. The existence of a link between $1 \mathrm{nRE}$ and $\mathrm{CO} 2$ emissions has been confirmed by Akadiri, Bekun, Taheri, and Akadiri (2019). lnURP is positively significant at $5 \%$ in all countries. It remains positively significant at $1 \%$ in BRICS countries and positively insignificant at OECD countries when segregated. This indicates that 1 nURP positively influences $\mathrm{CO}_{2}$ emission in OECD nations, although it is not significant. The findings of 1nURP on BRICS countries fall in line with the results of Liu et al. (2020) that "Urbanization has a positive and significant impact on $\mathrm{CO} 2$ emission in BRICS nations" (i.e., China, USA.. etc.).

In juxtaposing 2-stage least square (2SLS) results with GMM results, it is realized that they both produce similar outcomes. Findings from the Table below shows that EINT, 1nPNT, 1nR_D, 1nFDI, 1nGDPCAP, 1nGDPCAP2, 1nRE and 1nURP have identical results at 2SLS and GMM. Hence, we concluded that our findings are robust.

\subsection{Granger Causality Test}

Table 8 presents the Granger causality test results; this test reveals policy direction's outcome (Shahbaz, Lean, $\&$ Shabbir, 2012). From the Table, we observed one-way causal relationships and two-way causal relationships. The two-way causal relationships suggest that the feedback hypothesis exists in some of the samples regarding certain variables. Specifically, we observed that in all country's samples, EINT showed a one-way causal relationship with $\operatorname{lnCO} 2$, implying that energy intensity causes carbon emission but not vice versa. Moreover, lnGDPCAP and $\ln$ GDPCAP 2 also have a one-way causal relationship with $\ln \mathrm{CO} 2$, indicating that economic growth directly causes carbon emission. In contrast, lnR_D and lnRE showed a two-way causal relationship with $\operatorname{lnCO} 2$, suggesting that there is a bidirectional relationship that ensues between research and development expenditure, renewable energy consumption, and carbon emission, respectively, which are in line with the finding of Hongli and Vitenu-Sackey (2019) research.

However, in the BRICS countries sample, we observed that only lnURP showed a one-way causal relationship with $\operatorname{lnCO} 2$, implying that urban population growth causes carbon emission. Suffice it, and we watched a two-way causal relationship between $\ln \mathrm{R} \_\mathrm{D}, \operatorname{lnRE}$, and $\operatorname{lnCO} 2$, respectively.

Interestingly, the OECD countries' sample presents diverse outcomes from the other samples. Specifically, we observed that $\operatorname{lnGDPCAP}$ and $\operatorname{lnGDPCAP} 2$ showed a two-way causal relationship with $\operatorname{lnCO} 2$, a one-way causal relationship in all countries but insignificant in our BRICS countries sample. Again, $\operatorname{lnCO} 2$ has a one-way causal relationship with lnRE implying carbon emission has been causing a deteriorating impact on renewable energy consumption in OECD countries. On the other hand, we also observed a one-way causal relationship between EINT and $\ln \mathrm{CO} 2$, signalling that energy intensity causes carbon emission significantly. 
Table 8. Granger causality test.

\begin{tabular}{|c|c|c|c|c|c|c|}
\hline \multicolumn{7}{|l|}{$\begin{array}{l}\text { Pairwise Granger Causality } \\
\text { Tests }\end{array}$} \\
\hline & \multicolumn{2}{|c|}{ All Countries } & Brics & & OECD & \\
\hline Null Hypothesis: & F-Statistic & Sig. & F-Statistic & Sig. & F-Statistic & Sig. \\
\hline $\mathrm{EINT} \rightarrow \ln \mathrm{CO} 2$ & 14.269 & *** & 1.302 & & 6.404 & *** \\
\hline $\operatorname{lnCO} 2$ EINT & 2.067 & & 0.547 & & 2.293 & \\
\hline $\ln \mathrm{PNT} \ln \mathrm{CO} 2$ & 0.634 & & 1.358 & & 0.493 & \\
\hline $\ln \mathrm{CO} 2 \ln \mathrm{PNT}$ & 2.206 & & 0.192 & & 0.721 & \\
\hline $\ln \mathrm{R} \_\mathrm{D} \leftrightarrow \ln \mathrm{CO} 2$ & 4.647 & *** & 5.302 & *** & 1.290 & \\
\hline $\ln \mathrm{CO} 2 \leftrightarrow \ln \mathrm{R} \_\mathrm{D}$ & 2.496 & * & 6.684 & *** & 0.430 & \\
\hline $\operatorname{lnFDI} \ln \mathrm{CO} 2$ & 1.166 & & 2.250 & & 0.142 & \\
\hline $\ln \mathrm{CO} 2 \ln \mathrm{FDI}$ & 0.470 & & 0.242 & & 1.040 & \\
\hline $\ln \mathrm{GDPCAP} \rightarrow / \leftrightarrow \ln \mathrm{CO}_{2}$ & 35.641 & $* * *$ & 0.701 & & 29.351 & $* * *$ \\
\hline $\ln \mathrm{CO} 2 \leftrightarrow \ln \mathrm{GDPCAP}$ & 1.989 & & 1.403 & & 2.850 & * \\
\hline $\ln \mathrm{GDPCAP}_{2} \rightarrow / \leftrightarrow \ln \mathrm{CO} 2$ & 35.637 & **** & 0.728 & & 29.713 & **** \\
\hline $\ln \mathrm{CO} 2 \leftrightarrow \ln \mathrm{GDPCAP}_{2}$ & 2.026 & & 1.435 & & 2.960 & $* *$ \\
\hline $\ln \mathrm{RE} \leftrightarrow \ln \mathrm{CO}_{2}$ & 4.140 & *** & 2.449 & * & 1.708 & \\
\hline $\ln \mathrm{CO} 2 \leftrightarrow / \rightarrow \ln \mathrm{RE}$ & 2.425 & * & 4.066 & *** & 4.742 & $* *$ \\
\hline $\mathrm{URP} \rightarrow \ln \mathrm{CO} 2$ & 0.326 & & 3.309 & *** & 0.484 & \\
\hline $\operatorname{lnCO} 2 \ln U R P$ & 1.375 & & 1.121 & & 1.236 & \\
\hline
\end{tabular}

\section{CONCLUSION AND POLICY RECOMMENDATION}

This study was undertaken to investigate the impact of technology innovation, research and development, and energy intensity on carbon emission, with the help of data set sourced from the OECD and World Development Indicators database from 2005 to 2018 for 36 OECD and 5 BRICS countries. According to our findings, technological innovation impacts energy consumption and $\mathrm{CO} 2$ emissions in both BRICS and OECD countries. The findings suggest that technological innovation reduces $\mathrm{CO} 2$ emissions in both BRICS and OECD countries. In other words, technological advancements resulted in lower $\mathrm{CO} 2$ emissions while maintaining the same level of output. BRICS and OECD countries' $\mathrm{CO} 2$ emissions have improved due to technological progress, which has lowered $\mathrm{CO} 2$ emissions per unit of output both directly and indirectly. It is the responsibility of developed countries to ensure that newly developed technology is inexpensive and accessible to developing countries. When it comes to the critical dynamics of assessing technological innovation, R\&D spending, advanced technical export and import, and renewable energy use all play a significant role. We discovered that increasing research and development helps both BRICS and OECD countries reduce $\mathrm{CO} 2$ emissions significantly. Renewable energy consumption has a bidirectional relationship with research and development, and using renewable energy rather than non-renewable energy reduces $\mathrm{CO} 2$ emissions in all countries. Encouragement of renewable energy use is not always an efficient approach to reduce $\mathrm{CO} 2$ emissions for economies in need of development, such as the BRICS countries. They are encouraged to increase industries and acquire newly invented technologies in other to boost economic growth. Hence OECD nations have the task to make available freshly developed technologies to developing countries at affordable prices (Ding \& Asare, 2021).

The features of per capita $\mathrm{CO} 2$ emissions over time are critical for policymakers because they show whether a given intervention has a short- or long-term impact on the path. Here are some policies to consider: (i) Invest more in research and development. Based on our findings, we discovered that research and development play a critical role in $\mathrm{CO} 2$ emissions within the BRICS and OECD countries. As a result, the government invests in the development of low-carbon technology and energy efficiency improvements. Increase R\&D expenditure to construct compact cities, on the other hand. (ii) Optimize the industrial structure. Government should implement appropriate measures to reduce the number of industries within BRICS countries, while within OECD nations, the government should encourage industrialization. Hence, the government should develop the modern service 
industry with high technology content for BRICS nations. In coordinating the industrial structure and the environment, the government needs to make the current service industry the main driving force of economic growth. (iii) Modification of energy consumption. Renewable energy is vital in maintaining development in both BRICS and OECD countries. The government can control the use of fossil energy by imposing a carbon tax to achieve low-carbon growth. On the other hand, most of the developing countries rely on the importation of renewable energy technologies from a developed nation: Hence the government of those developing countries should formulate relevant policies to encourage various industries to use renewable energy (wind, solar, geothermal, bio-energy) instead of non-renewable energy (coal, petroleum) in the manufacturing process by subsiding the prices of renewable technologies. Finally, due to space constraints and the computational simulation's complexity, this work only examined the impact of technical innovation, R\&D, and energy intensity on carbon dioxide emissions in all countries, including BRICS and OECD countries. However, future research can look into more comprehensive economic governance policies that include a wider range of sectors worldwide to simulate a more realistic situation.

Table 9. Variables measurement and description.

\begin{tabular}{|c|c|c|c|}
\hline Variables & Measurement & Description & Source \\
\hline $\operatorname{lnCO} 2$ & Carbon emission & $\begin{array}{l}\text { Carbon dioxide per metric ton and } \\
\text { Nitroxide emission per metric tons }\end{array}$ & OECD database \\
\hline lnR_D, & Ecological innovation & $\begin{array}{l}\text { Research and Development Expenditure } \\
\text { (R\&D) US } \$ \text { million }\end{array}$ & OECD database \\
\hline EINT & Ecological innovation & $\begin{array}{l}\text { Energy intensity }=\text { primary energy } \\
\text { use/GDP per capita US } \$ \text { million }\end{array}$ & \\
\hline $\operatorname{lnPNT}$ & Ecological innovation & $\begin{array}{lll}\begin{array}{l}\text { Patent registration } \\
\text { registration) }\end{array} & \text { (Numer of } \\
\end{array}$ & \\
\hline $\begin{array}{l}\text { 1.LnGDPCAP } \\
\text { 2.lnGDPCAP2 }\end{array}$ & Economic growth & $\begin{array}{l}\text { 1.GDP per capita US } \$ \text { thousand PPP } \\
\text { 2.Square root of lnGDPCAP: quadratic } \\
\text { term of Economic growth }\end{array}$ & OECD database \\
\hline URP & Urbanization & $\begin{array}{l}\text { Urban population (people living in } \\
\text { metropolitan and urban cities as } \% \text { of the } \\
\text { total population) }\end{array}$ & $\begin{array}{l}\text { World Development } \\
\text { Indicators-World Bank }\end{array}$ \\
\hline $\operatorname{lnFDI}$ & $\begin{array}{ll}\text { Foreign } & \text { direct } \\
\text { investment }\end{array}$ & Net inflows US $\$$ million & OECD database \\
\hline $\ln R E$ & $\begin{array}{l}\text { Renewable } \text { Energy } \\
\text { Consumption }\end{array}$ & $\%$ final energy consumption & OECD database \\
\hline
\end{tabular}

Table 10. List of Countries.

\begin{tabular}{l|l|l}
\hline OECD Countries & OECD Countries & OECD Countries \\
\hline Australia & Korea & United States \\
\hline Austria & Luxembourg & Chile \\
\hline Belgium & Mexico & Estonia \\
\hline Canada & Netherlands & Israel \\
\hline Czech Republic & New Zealand & Slovania \\
\hline Denmark & Norway & \\
\hline Finland & Poland & BRICS Countries \\
\hline France & Portugal & Brazil \\
\hline Germany & Slovak Republic & Russia \\
\hline Hungary & Spain & India \\
\hline Iceland & Sweden & China \\
\hline Ireland & Switzerland & South Africa \\
\hline Italy & Turkey & \\
\hline Japan & United Kingdom & \\
\hline
\end{tabular}


Funding: This study received no specific financial support.

Competing Interests: The authors declare that they have no competing interests.

Acknowledgement: All authors contributed equally to the conception and design of the study.

\section{REFERENCES}

Aghion, P., Hemous, D., \& Veugelers, R. (2009). No green growth without innovation. Bruegel Policy Brief 2009/07, November 2009: 8 .

Akadiri, S. S., Bekun, F. V., Taheri, E., \& Akadiri, A. C. (2019). Carbon emissions, energy consumption and economic growth: A causality evidence. International Journal of Energy Technology and Policy, 15(2-3), 320-336. Available at: https://doi.org/10.1504/ijetp.2019.10019648.

Asare, P., \& Barfi, R. (2021). The impact of covid-19 pandemic on the global economy: Emphasis on poverty alleviation and economic growth. Economics, 8(1), 32-43. Available at: https://doi.org/10.18488/journal.29.202 1.81.32.43.

Asare, P., \& Hongli, J. (2020). Financial inclusion and poverty alleviation: The contribution of commercial banks in West Africa. International Journal of Business, 7(1), 57-70. Available at: https://doi.org/10.18488/journal.62.2020.71.57.70.

Baker, E., Clarke, L., \& Weyant, J. (2006). Optimal technology R\&D in the face of climate uncertainty. Climatic Change, 78, 157179. Available at: https://doi.org/10.1007/s 10584-006-9092-8.

Bala, S. M., \& Kumar, R. S. (2011). Technological innovations and energy intensity of machine tool SMEs in Bangalore: Do process innovations contribute to energy efficiency? International Journal of Energy Technology and Policy, 7(5-6), 519536. Available at: https://doi.org/10.1504/ijetp.2011.045237.

Ball, L. (2014). Long-term damage from the great recession in OECD countries. European Journal of Economics and Economic Policies: Intervention, 11(2), 149-160. Available at: https://doi.org/10.4337/ejeep.2014.02.02.

Carraro, C., \& Siniscalco, D. (1994). Voluntary agreements in enviromental policy; a theoretical appraisal: Fondazione ENI Enrico Mattei.

Carraro, C., \& Siniscalco, D. (1996). Voluntary agreements in environmental policy; a theoretical appraisal, in Oates, W.E. (Ed.) Economic Policy for the Environment and Natural Resources: Techniques for the Management and Control of Pollution (pp. 80-94): Fondazione ENI Enrico Mattei.

Cheng, M., Qin, Z., Hu, J., Liu, Q., Wei, T., Li, W., \& Liu, B. (2020). Facile and rapid one-step extraction of carboxylated cellulose nanocrystals by $\mathrm{H} 2 \mathrm{SO} 4 / \mathrm{HNO} 3$ mixed acid hydrolysis. Carbohydrate Polymers, 231, 115701. Available at: https://doi.org/10.1016/j.carbpol.2019.115701.

Ding, G., \& Asare, P. (2021). Central bank independence and economic growth of Ghana: What inflation and GDP per capita growth rates matter? Economics, 8(1), 104-116. Available at: https://doi.org/10.18488/journal.29.202 1.81.104.116.

Ding, G., Vitenu-Sackey, P. A., Chen, W., Shi, X., Yan, J., \& Yuan, S. (2021). The role of foreign capital and economic freedom in sustainable food production: Evidence from DLD countries. Plos One, 16(7), e0255186. Available at: https://doi.org/10.1371/journal.pone.0255186.

Fisher-Vanden, K., Jefferson, G. H., Liu, H., \& Tao, Q. (2004). What is driving China's decline in energy intensity? Resource and Energy Economics, 26(1), 77-97.

Geneva. (2021). Technology and innovation report 2021. Retrieved from https://shop.un.org.

Goulder, L. H., \& Mathai, K. (2000). Optimal $\mathrm{CO} 2$ abatement in the presence of induced technological change. Journal of Environmental Economics and Management, 39(1), 1-38. Available at: https://doi.org/10.1006/jeem.1999.1089.

Goulder., L. H., \& Schneider, S. H. (1999). Induced technological change and the attractiveness of $\mathrm{CO} 2$ abatement policies. Resource and Energy Economics, 21(3-4), 21 1-253. Available at: https://doi.org/10.1016/s0928-7655(99)00004-4.

Hoffert, M. I., Caldeira, K., Benford, G., Criswell, D. R., Green, C., Herzog, H., \& Lewis, J. S. (2002). Advanced technology paths to global climate stability: Energy for a greenhouse planet. Science, 298(5595), 981-987. Available at: https://doi.org/10.1126/science.1072357. 
Hongli, J., \& Vitenu-Sackey, P. (2019). The impact of renewable energy consumption and FDI on carbon emission: An empirical analysis for 15 African countries using panel cointegration regression model. International Journal of Management Sciences and Business Research, 8(7), 14-22.

Im, K. S., Pesaran, M. H., \& Shin, Y. (2003). Testing for unit roots in heterogeneous panels. Journal of Econometrics, 115(1), 5374. Available at: https://doi.org/10.1016/s0304-4076(03)00092-7.

Jaffe, A. B., Newell, R. G., \& Stavins, R. N. (2005). A tale of two market failures: Technology and environmental policy. Ecological Economics, 54(2-3), 164-174. Available at: https://doi.org/10.1016/j.ecolecon.2004.12.027.

Kao, C. (1999). Spurious regression and residual-based tests for cointegration in panel data. Journal of Econometrics, 90(1), 1-44. Available at: https://doi.org/10.1016/s0304-4076(98)00023-2.

Levin, A., Lin, C.-F., \& Chu, C.-S. J. (2002). Unit root tests in panel data: Asymptotic and finite-sample properties. Journal of Econometrics, 108(1), 1-24. Available at: https://doi.org/10.1016/s0304-4076(01)00098-7.

Liu, J.-L., Ma, C.-Q., Ren, Y.-S., \& Zhao, X.-W. (2020). Do real output and renewable energy consumption affect CO2 emissions? Evidence for selected BRICS countries. Energies, 13(4), 1-18. Available at: https://doi.org/10.3390/en 13040960.

Maddala, G. S., \& Wu, S. (1999). A comparative study of unit root tests with panel data and a new simple test. Oxford Bulletin of Economics and statistics, 61(S1), 631-652. Available at: https://doi.org/10.1111/1468-0084.61.s1.13.

Mulder, P., \& De Groot, H. L. (2012). Structural change and convergence of energy intensity across OECD countries, 19702005. Energy Economics, 34(6), 1910-1921. Available at: https://doi.org/10.1016/j.eneco.2012.07.023.

Nawaz, M. A., Hussain, M. S., Kamran, H. W., Ehsanullah, S., Maheen, R., \& Shair, F. (2021). Trilemma association of energy consumption, carbon emission, and economic growth of BRICS and OECD regions: Quantile regression estimation. Environmental Science and Pollution Research, 28(13), 16014-16028. Available at: https://doi.org/10.1007/s11356-02011823-8.

Németh-Durkó, E. (2020). Determinants of carbon emissions in a European emerging country: Evidence from ARDL cointegration and Granger causality analysis. International Journal of Sustainable Development \& World Ecology, 28(5), 417-428. Available at: https://doi.org/10.1080/13504509.2020.1839808.

Niu, J. (202 1). The impact of technological innovation on carbon emissions. Paper presented at the E3S Web of Conferences.

Pao, H.-T., \& Tsai, C.-M. (2011). Modeling and forecasting the $\mathrm{CO} 2$ emissions, energy consumption, and economic growth in Brazil. Energy, 36(5), 2450-2458. Available at: https://doi.org/10.1016/j.energy.2011.01.032.

Requate, T., \& Unold, W. (2003). Environmental policy incentives to adopt advanced abatement technology: Will the true ranking please stand up? European Economic Revierw, 47(1), 125-146. Available at: https://doi.org/10.1016/s0014$2921(02) 00188-5$.

Santra, S. (2017). The effect of technological innovation on production-based energy and $\mathrm{CO} 2$ emission productivity: Evidence from BRICS countries. African Journal of Science, Technology, Innovation and Development, 9(5), 503-512. Available at: https://doi.org/10.1080/20421338.2017.1308069.

Seager, J., Bechtel, J., Bock, S., \& Dankelman, I. (2016). Global gender and environment outlook. Nairobi, Kenya: United Nations Environment Programme (UNEP).

Shahbaz, M., Lean, H. H., \& Shabbir, M. S. (2012). Environmental Kuznets curve hypothesis in Pakistan: Cointegration and Granger causality. Renewable and Sustainable Energy Reviews, 16(5), 2947-2953. Available at: https://doi.org/10.1016/j.rser.2012.02.015.

Sharma, R., Sinha, A., \& Kautish, P. (2021). Do economic endeavors complement sustainability goals in the emerging economies of South and Southeast Asia? Management of Environmental Quality: An International Journal, 32(3), 524- 542. Available at: https://doi.org/10.1108/meq-10-2020-0218.

Sinha, A., \& Shahbaz, M. (2018). Estimation of environmental Kuznets curve for $\mathrm{CO} 2$ emission: Role of renewable energy generation in India. Renewable Energy, 119, 703-711. Available at: https://doi.org/10.1016/j.renene.2017.12.058. 
Socolow, R., Hotinski, R., Greenblatt, J. B., \& Pacala, S. (2004). Solving the climate problem: Technologies available to curb CO2 emissions. Environment: Science and Policy for Sustainable Development, 46(10), 8-19. Available at: https://doi.org/10.1080/00139150409605818.

Soytas, U., Sari, R., \& Ewing, B. T. (2007). Energy consumption, income, and carbon emissions in the United States. Ecological Economics, 62(3-4), 482-489. Available at: https://doi.org/10.1016/j.ecolecon.2006.07.009.

Takanabe, K., Kamata, K., Wang, X., Antonietti, M., Kubota, J., \& Domen, K. (2010). Photocatalytic hydrogen evolution on dyesensitized mesoporous carbon nitride photocatalyst with magnesium phthalocyanine. Physical Chemistry Chemical Physics, 12(40), 13020-13025. Available at: https://doi.org/10.1039/c0cp00611d.

Vitenu-Sackey, P. A., \& Bathuure, I. A. (2020). Does government expenditure on secondary education affect economic growth and secondary school enrollment? An empirical evidence of Ghana. International Journal of Business, Information and Management, 12(3), 38-50.

Vitenu-Sackey., P. A. (2020). Financial development, foreign direct investment and carbon emissions: A comparative study of West Africa and Southern Africa Regions. International Review of Research in Emerging Markets and the Global Economy (IRREM), 6(1), 1550-1569.

Voigt, S., De Cian, E., Schymura, M., \& Verdolini, E. (2014). Energy intensity developments in 40 major economies: structural change or technology improvement? Energy Economics, 41, 47-62. Available at: https://doi.org/10.1016/j.eneco.2013.10.015.

Wang, Q., \& Zhang, F. (2020). Does increasing investment in research and development promote economic growth decoupling from carbon emission growth? An empirical analysis of BRICS countries. Journal of Cleaner Production, 252, 119853. Available at: https://doi.org/10.1016/j.jclepro.2019.119853.

Willems, S., \& Baumert, K. (2003). OECD environment directorate international energy agency institutional capacity and climate actions. Working Paper Number COM/ENV/EPOC/IEA/SLT(2003)5. OECD Environment Directorate, Paris- France. Retrieved from: http://www.oecd.org/env/cc/.

Wurlod, J.-D., \& Noailly, J. (2018). The impact of green innovation on energy intensity: an empirical analysis for 14 industrial sectors in OECD countries. Energy Economics, 71, 47-61. Available at: https://doi.org/10.1016/j.eneco.2017.12.012.

Views and opinions expressed in this article are the views and opinions of the author(s), International Journal of Sustainable Development E World Policy shall not be responsible or answerable for any loss, damage or liability etc. caused in relation to/arising out of the use of the content. 